\title{
RESEARCH
}

Open Access

\section{Potential of entomopathogenic nematode isolates from Rwanda to control the tomato leaf miner, Tuta absoluta (Meyrick) (Lepidoptera: Gelechiidae)}

Assinapol Ndereyimana ${ }^{1,2^{*}}$ (D, Samuel Nyalala ${ }^{1}$, Patrick Murerwa ${ }^{1}$ and Svetlana Gaidashova ${ }^{2}$

\begin{abstract}
Tomato leaf miner, Tuta absoluta (Meyrick), is a major threat to tomato production as it can cause up to 100\% yield loss under both greenhouse and open-field conditions. Chemical control, which is associated with several undesirable effects, remains the only option readily available for this pest since its invasion of Rwanda in the year 2015. This study assessed the potential of using local isolates of entomopathogenic nematodes (EPNs) in management of T. absoluta in Rwanda. Six EPNs including four locally isolated strains: Steinernema sp. RW14-M-C2a-3, Steinernema sp. RW14-M-C2b-1, S. carpocapsae RW14-G-R3a-2 and Heterorhabditis bacteriophora RW14-N-C4a, and two exotic species: S. carpocapsae All and H. bacteriophora H06 were evaluated. Three bioassays were conducted in the laboratory, using a tomato leaflet with third instar T. absoluta larva in gallery and 9-cm Petri dishes as bioassay arenas in a completely randomized design with three replications. The EPNs were applied at a volume of $1 \mathrm{ml}$ containing 500 infective juveniles per leaflet, while sterile tap water was used as negative control. Larval mortality was checked continuously for $96 \mathrm{~h}$ at $24 \mathrm{~h}$ interval. The results revealed that all the tested EPNs were able to find and kill T. absoluta larvae inside the leaf galleries; and their efficacy increased with exposure time. The pathogenicity effects were significantly different $(p<0.05)$ among EPNs. In the first $24 \mathrm{~h}$ after inoculation, the efficacy of local EPN isolates (53.396.7\%) was significantly higher than the one of exotic species (0.0-26.7\%). The efficacy of three Rwandan EPN isolates, Steinernema sp. RW14-M-C2a-3, Steinernema sp. RW14-M-C2b-1, and S. carpocapsae RW14-G-R3a-2 was not significantly different from 24 to $96 \mathrm{~h}$ after inoculation, except for S. carpocapsae RW14-G-R3a-2 during $24 \mathrm{~h}$ after inoculation in bioassay 3. There was insignificant difference among all the EPN isolates after $96 \mathrm{~h}$ of exposure. This is the first study carried out in Rwanda that investigated the potential of locally isolated EPNs against T. absoluta. Field experiments should be conducted to fully explore the possibilities of using local EPN isolates in integrated pest management of T. absoluta in Rwanda.
\end{abstract}

Keywords: Tuta absoluta, Entomopathogenic nematodes, Heterorhabditis, Steinernema, Local isolates, Biological control, Rwanda

\footnotetext{
* Correspondence: assinapol@gmail.com

${ }^{1}$ Department of Crops, Horticulture and Soils, Egerton University, Nakuru,

Kenya

${ }^{2}$ Agriculture Research and Technology Transfer Department, Rwanda

Agriculture and Animal Resources Development Board (RAB), Kigali, Rwanda
} 


\section{Background}

Tomato leaf miner, Tuta absoluta (Meyrick) (Lepidoptera: Gelechiidae), is an invasive pest originating from South America and was detected for the first time in Rwanda in the year 2015 (FAO, 2015). This pest is the major threat to tomato production as it can cause up to $100 \%$ yield loss under both greenhouse and open-field conditions (Desneux et al., 2010 and Biondi et al., 2018). It has also been reported in other Solanaceae crops, like eggplant (Solanum melongena L.), potato (Solanum tuberosum L.), pepper (Capsicum annuum L.), nightshade (Solanum nigrum L.), and tobacco (Nicotiana tabacum L.) (Ferracini et al. 2012).

Chemical control remains the only option readily available in areas newly infested by T. absoluta (Brévault et al. 2014). However, the short developmental period of this pest and its many generations per year lead to numerous insecticide sprays in one season (Biondi et al. 2018). This facilitates the development of resistant pest strains to frequently used insecticides (Haddi et al. 2017) and leads to the destruction of natural enemies (Macharia et al. 2009). The mine-feeding behavior of T. absoluta larva also limits the effectiveness of synthetic insecticides (Gebremariam, 2015). The limited effectiveness in addition to hazardous nature of chemical insecticides (Macharia et al. 2009), trigger the need for integrated pest management (IPM) and use of pest control actions that assure positive economic, ecological, and sociological effects (Blake et al. 2007).

Since $T$. absoluta is a major threat to tomato production in Rwanda, it is important to develop sustainable mechanisms to cope with it so as to sustain the role of tomato in diversifying the economy, alleviating poverty, and improving nutrition (Clay and Turatsinze, 2014). Biological control is one of the safe ways of managing agricultural pests as it has no harmful effects on environment and human health. Among biological control methods, entomopathogenic nematodes (EPNs) have the potential of being used effectively against $T$. absoluta (Van Damme et al. 2016 and Biondi et al. 2018). The potential of EPNs was also evidenced against a diversity of other economically important pests (Wraight et al. 2017). However, no research had been conducted in Rwanda to explore the possibilities of including these EPNs in IPM of tomato crop.

Entomopathogenic nematodes belong predominantly to Steinernematidae and Heterorhabditidae families; they are obligate parasites that kill insects with the help of mutualistic bacteria (Xenorhabdus spp. and Photorhabdus spp., respectively) which live in gut of infective juveniles (IJs) (Campos-Herrera, 2015). They can be effective against many soilborne pests and others which live in galleries due to the conducive environment (protection against desiccation and ultraviolet light) for their IJs (Garcia-del-Pino et al., 2013). The IJs, which are the only free-living stage (third stage) enters the host body via the natural openings or even through the soft body. Once inside the body, the bacteria cells released by IJs multiply quickly and kill the host in 24-72 h (Gözel and Kasap, 2015). Moreover, these bacterial cells digest host tissues and release antibiotics which protect the killed host against saprophytes and scavengers, thus permitting the nematodes to develop and reproduce (Griffin et al. 2005). There might be one to three nematode generations depending on the size of the host. When host nutrients are exhausted, the IJs sequester the bacteria in their intestines, leave the host and search for a new one; but when they miss a new host, the IJs are able to persist for months in moist soil (Stock, 2015).

It is recognized that the environment determines the success or failure of EPNs because of the possible differences in persistence, virulence, host range, and familiarity to habitats between local and non-local EPN isolates (Lacey and Georgis, 2012). The target host and the environment where EPNs will be applied should be considered when designing a control program using EPNs. Thus, screening several nematode isolates against a particular target host in a specific environment is prerequisite in development of any control program using EPNs (Biondi et al. 2018).

Four new EPN strains were isolated from semi-natural and small-holder farming habitats of Rwanda and maintained in Biological Control Laboratory at Rwanda Agriculture and Animal Resources Development Board (RAB) (Yan et al. 2016).

The objective of this study was to determine the potential of the EPNs against T. absoluta under laboratory conditions.

\section{Materials and methods}

The present study was carried out in Biological Control Laboratory-EPN Production Facility of Rwanda Agriculture and Animal Resources Development Board (RAB) (Holmes et al. 2015). The average annual rainfall and temperature of the locality are $1039 \mathrm{~mm}$ and $19{ }^{\circ} \mathrm{C}$, respectively (Ndabamenye et al. 2013).

\section{Source and mass production of EPNs}

Six EPNs including four local isolates and two exotic species, maintained in the Biological Control Laboratory-EPN Production Facility of RAB were used for the study. The local EPNs were Steinernema sp. RW14-M-C2a-3, Steinernema sp. RW14-M-C2b-1, S. carpocapsae RW14-G-R3a-2, and Heterorhabditis bacteriophora RW14-N-C4a, which were isolated from semi-natural and small-holder farming habitats of Rwanda in the year 2014 (Yan et al. 2016). The two exotic EPN species, $S$. carpocapsae All and H. bacteriophora H06, were obtained from Lvbenyan Biotech Ltd., Guangdong Institute of Applied Biological Resources (GIABR) in China (Kajuga et al. 2018). The exotic species 
were used as standard checks since they are among the most used for control of foliar and soil insect pests (Lacey and Georgis, 2012).

In vivo method of EPN mass production was followed in the aforesaid laboratory, using last instar larvae of Galleria mellonella L. (Lepidoptera: Pyralidae), which is mostly used for this purpose as it is easily infested by nematodes (Kaya and Stock, 1997). The G. mellonella larvae, killed by EPNs, were moved to a white trap (White, 1927) for the IJs to come out of the cadavers. IJs were harvested, rinsed in distilled water, and stored at $7{ }^{\circ} \mathrm{C}$ for less than 1 week. Since EPNs do not go through complete dormancy stage and continue to consume their limited energy during storage (Mahmoud, 2016), they were used in bioassays when still fresh within a period of less than 7 days following their harvesting from white trap. Before using the EPNs, they were allowed to acclimatize at room temperature for $1 \mathrm{~h}$, and their viability was checked under a stereomicroscope with $\times 60$ magnification, where live IJs were moving actively (Garcia-Del-Pino et al. 2013). These EPNs were used in bioassay once more than $90 \%$ of IJs were viable (Kajuga et al. 2018).

\section{Source of $T$. absoluta larvae}

To secure the source of laboratory specimens (tomato leaflets with $T$. absoluta larvae inside the galleries) a field of tomato, Solanum lycopersicum cv. Roma, was established in Bugesera District, Rweru Sector. This area was selected because it is the hot spot of T. absoluta infestation in Rwanda. Tomato crop was established in November, 2018 ( 2 months before starting bioassays) following the package recommended for field cultivation of the crop in Rwanda. However, insecticides were not applied from 2 weeks after planting to favor quick development of T. absoluta in the field. Tomato leaflets containing $T$. absoluta larvae inside the galleries were harvested from this naturally infested tomato field with caution to have only one larva per leaflet. These leaflets were transported in a cloth bag to the laboratory and kept for a maximum of $12 \mathrm{~h}$ before being used in bioassays.

\section{Pathogenicity test}

An hour before each bioassay, nematode concentrations were calculated as per Navon and Ascher (2000) and adjusted to the required concentration of $500 \mathrm{IJs} / \mathrm{ml}$ (Batalla-Carrera et al. 2010; Youssef, 2015 and Mutegi et al. 2017) using sterile tap water. The leaflets containing third instar T. absoluta larvae in galleries were carefully selected for use in bioassay. Each leaflet was positioned in a 9-cm diameter Petri dish having 3 moistened filter paper discs at its base and 10 Petri-dishes were used per treatment in each replication. Thereafter, $1 \mathrm{ml}$ of water containing $500 \mathrm{IJs}$ of EPNs was applied on both sides of each leaflet, using sterilized pipette for each EPN isolate (Batalla-Carrera et al. 2010) and sterile tap water was used as control. The Petri dishes were sealed by parafilm to protect them against dehydration and prevent escape of the larvae. The Petri dishes were then maintained at a temperature of $25 \pm 2{ }^{\circ} \mathrm{C}$ in dark. Fresh leaflets were added after 2 days to prevent starvation of larvae. Each bioassay was carried out in a completely randomized design with three replications and three bioassays were conducted from January to February, 2019.

\section{Data collection and analysis}

Petri dishes were opened 24, 48, 72, and $96 \mathrm{~h}$ after inoculation to check the status of larvae whether dead or alive. Dead larvae were recognized by being unable to respond to stereoscopic light or to probing by camel's hair brush tip (Van Damme et al. 2016). Dead and alive larvae at the end of bioassay were dissected under the stereomicroscope to determine the presence or absence of nematodes in their body (Kajuga et al. 2018). The number of dead larvae at each observation period was used to compute the observed mortality (\%), which was obtained by dividing the number of dead larvae per treatment by the total number of larvae per treatment and multiplying the result by hundred. When there was mortality in Petri dishes treated with water, this was considered as natural mortality and was used to correct the mortality observed in Petri dishes, where EPNs were applied. This correction was done using Schneider-Orelli's formula (Püntener, 1981) as follows:

$$
\text { Corrected mortality }=\frac{\text { Observed mortality }(\%) \text {-control mortality }}{100 \text {-control mortality }} \times 100 \text {. }
$$

Data were checked for normality before subjecting them to statistical analysis, using proc univariate procedures of SAS. Data on corrected mortality at $48 \mathrm{~h}$ and $72 \mathrm{~h}$ after inoculation were arcsine transformed as per Rangaswamy (2013). General linear model (GLM) was used to determine whether the effect of EPNs on $T$. absoluta larvae mortality was significantly different or not. Tukey's honestly significant difference (HSD) test was used to separate the means. These analyses were performed, using Statistical Analysis System package SAS software version 9.2 (SAS Institute, 2010), and the level of significance was fixed at $5 \%$.

\section{Results and discussion}

All EPN isolates evaluated were able to find, infect, and kill T. absoluta larvae inside the tomato leaf galleries, however, with different levels of pathogenicity (Table 1). The recorded mortality differed significantly among the tested EPNs. However, there was an insignificant difference among EPNs $(P>0.05)$ after $72 \mathrm{~h}$ of exposure for bioassay 2 and after $96 \mathrm{~h}$ of exposure for all bioassays. When data (arcsine transformed) were analyzed considering exposure 
Table 1 GLM analysis for mortality of Tuta absoluta larvae caused by different EPNs used at $500 \mathrm{IJs} / \mathrm{ml}$

\begin{tabular}{|c|c|c|c|c|c|}
\hline Bioassay & Sources of variation & $d f$ & $F$ & $P$ & Significance \\
\hline \multirow[t]{6}{*}{ One } & EPNs at $24 \mathrm{~h}$ of exposure & 5,12 & 48.29 & $<0.0001$ & *** \\
\hline & EPNs at $48 \mathrm{~h}$ of exposure & 5,12 & 9.95 & 0.0006 & $* * *$ \\
\hline & EPNs at $72 \mathrm{~h}$ of exposure & 5,12 & 71.06 & $<0.0001$ & $* * *$ \\
\hline & EPNs at $96 \mathrm{~h}$ of exposure & 5,12 & 1.00 & 0.4582 & ns \\
\hline & Exposure time & 3,48 & 95.49 & $<0.0001$ & $* * *$ \\
\hline & EPNs $\times$ exposure time & 15,48 & 7.36 & $<0.0001$ & $* * *$ \\
\hline \multirow[t]{6}{*}{ Two } & EPNs at $24 \mathrm{~h}$ of exposure & 5,12 & 27.46 & $<0.0001$ & $* * *$ \\
\hline & EPNs at $48 \mathrm{~h}$ of exposure & 5,12 & 423.82 & $<0.0001$ & $* * *$ \\
\hline & EPNs at $72 \mathrm{~h}$ of exposure & 5,12 & 3.09 & 0.0508 & ns \\
\hline & EPNs at $96 \mathrm{~h}$ of exposure & 5,12 & - & - & ns \\
\hline & Exposure time & 3,48 & 95.04 & $<0.0001$ & $* * *$ \\
\hline & EPNs $\times$ exposure time & 15,48 & 12.86 & $<0.0001$ & $* * *$ \\
\hline \multirow[t]{6}{*}{ Three } & EPNs at $24 \mathrm{~h}$ of exposure & 5,12 & 204.85 & $<0.0001$ & $* * *$ \\
\hline & EPNs at $48 \mathrm{~h}$ of exposure & 5,12 & 32.69 & $<0.0001$ & $* * *$ \\
\hline & EPNs at $72 \mathrm{~h}$ of exposure & 5,12 & 4.82 & 0.0119 & * \\
\hline & EPNs at $96 \mathrm{~h}$ of exposure & 5,12 & - & - & ns \\
\hline & Exposure time & 3,48 & 153.75 & $<0.0001$ & $* * *$ \\
\hline & EPNs $\times$ exposure time & 15,48 & 19.28 & $<0.0001$ & $* * *$ \\
\hline
\end{tabular}

* and *** show significance at $P<0.05$ and $P<0.001$, respectively; $n s$ indicates non-significance; the sign - indicates where GLM was not possible because there was no variation between treatments; One, Two, and Three are the bioassays conducted

time and EPNs $\times$ exposure time combination as treatments, it was observed that both affected significantly $(P<0.001)$ T. absoluta larval mortality (Table 1 ). This implies that efficacy of the tested EPNs depends on exposure time.

In the first $24 \mathrm{~h}$ after inoculation, the efficacy of all local EPN isolates was significantly higher than the two exotic EPN species in the three bioassays $(P<0.001)$, except for $H$. bacteriophora RW14-N-C4a in bioassay 2 . At $48 \mathrm{~h}$ after inoculation, the efficacy of $H$. bacteriophora H06 was insignificantly different from the one of local EPN isolates in bioassays 1 and 3; but this lasted 72 $\mathrm{h}$ in bioassay 2 . In $72 \mathrm{~h}$ post-inoculation, all local EPN isolates had achieved $100 \%$ mortality in all bioassays, except $H$. bacteriophora RW14-N-C4a, which had 96.3\% in bioassay 3 . The maximum mortality was achieved on different times of exposure to EPNs, ranging from 48 to $96 \mathrm{~h}$ (Table 2).

Among the local (Rwandan) EPN isolates, three, Steinernema sp. RW14-M-C2a-3, Steinernema sp. RW14-M-C2b-1 and S. carpocapsae RW14-G-R3a-2, remained insignificantly different in efficacy from 24 to $96 \mathrm{~h}$ after inoculation, except that $S$. carpocapsae RW14-G-R3a-2 was significantly different from them only during $24 \mathrm{~h}$ after inoculation in bioassay 3. H. bacteriophora RW14-N-C4a joined their group $48 \mathrm{~h}$ after inoculation for bioassays 1 and 2 and $72 \mathrm{~h}$ for bioassay 3 ; which revealed that it was not as effective. Here, EPNs belonging to Steinernema genus were more effective than the ones belonging to Heterorhabditis (Table 2).
The ability of EPNs to reach and kill T. absoluta larvae in leaf galleries was also reported by Batalla-Carrera et al. (2010), Van Damme et al. (2016), and Kamali et al. (2018). The local EPN isolates were able to kill T. absoluta and had even been found to be effective against white grubs in Rwanda (Kajuga et al. 2018), while it was not easy to find EPNs which can kill them (Laznik and Trdan, 2015). Although EPNs live naturally in soil, different researchers found that they can be used on above-ground parts of the plant to control effectively the pests living in cryptic habitats like in leaf galleries (Batalla-Carrera et al. 2010 and Garcia-del-Pino et al. 2013); which concurs with the results of the present study under laboratory conditions.

In the present study, the third instar larvae were used; other studies revealed that EPNs were able to find and kill all the four larval instars inside or outside the leaf galleries (Batalla-Carrera et al. 2010 and Van Damme et al. 2016). Batalla-Carrera et al. (2010) found that T. absoluta larval stage was the most vulnerable to EPNs. They thus emphasized the necessity to apply EPNs on the above-ground part of tomato plant to ensure effective control of this pest using the most suitable isolates against a particular pest in a given environment.

Different pathogenicity levels displayed by the studied EPNs agree with other studies, using different EPN isolates (Gözel and Kasap, 2015 and Van Damme et al. 2016). This underlines the necessity of EPNs screening 
Table 2 Daily mortality of T. absoluta larvae (mean \pm SD) in leaf galleries treated with local and exotics EPNs using the concentration of $500 \mathrm{Js} / \mathrm{ml}$

\begin{tabular}{|c|c|c|c|c|}
\hline \multirow[t]{2}{*}{ EPN isolates/strains } & \multicolumn{4}{|c|}{ T. absoluta larval mortality (\%) } \\
\hline & $24 \mathrm{~h}$ & $48 \mathrm{~h}$ & $72 \mathrm{~h}$ & $96 \mathrm{~h}$ \\
\hline \multicolumn{5}{|l|}{ Bioassay 1} \\
\hline St. sp. RW14-M-C2a-3 & $80.0( \pm 10.0) \mathrm{a}$ & $96.7( \pm 5.8)$ a & $100( \pm 0.0) \mathrm{a}$ & $100( \pm 00.) \mathrm{a}$ \\
\hline St. sp. RW14-M-C2b-1 & $83.3( \pm 15.3)$ a & $92.5( \pm 6.6)$ a & $100( \pm 0.0)$ a & $100( \pm 0.0) \mathrm{a}$ \\
\hline St. carp. RW14-G-R3a-2 & $96.7( \pm 5.8)$ a & $95.8( \pm 7.2) \mathrm{a}$ & $100( \pm 0.0)$ a & $100( \pm 0.0) \mathrm{a}$ \\
\hline Het. bact. RW14-N-C4a & $53.3( \pm 5.8) b$ & $96.7( \pm 5.8)$ a & $100( \pm 0.0)$ a & $100( \pm 0.0) \mathrm{a}$ \\
\hline St. carp. All & $6.7( \pm 5.8) c$ & $40.0( \pm 10.0) b$ & $84.7( \pm 6.1) b$ & $95.8( \pm 7.2) \mathrm{a}$ \\
\hline Het. bact. H06 & $26.7( \pm 5.8) c$ & $85.8( \pm 5.2) \mathrm{a}$ & $100( \pm 0.0)$ a & $100( \pm 0.0) \mathrm{a}$ \\
\hline CV & 15.26 & 13.21 & 2.21 & 2.97 \\
\hline \multicolumn{5}{|l|}{ Bioassay 2} \\
\hline St. sp. RW14-M-C2a-3 & $83.3( \pm 20.8) a b$ & $100( \pm 0.0)$ a & $100( \pm 0.0)$ a & $100( \pm 0.0) \mathrm{a}$ \\
\hline St. sp. RW14-M-C2b-1 & $96.7( \pm 5.8) \mathrm{a}$ & $100( \pm 0.0)$ a & $100( \pm 0.0)$ a & $100( \pm 0.0) \mathrm{a}$ \\
\hline St. carp. RW14-G-R3a-2 & $90.0( \pm 10.8)$ a & $100( \pm 00$.$) a$ & $100( \pm 0.0)$ a & $100( \pm 0.0) \mathrm{a}$ \\
\hline Het. bact.RW14-N-C4a & $53.3( \pm 11.5) b c$ & $100( \pm 0) \mathrm{a}$ & $100( \pm 0) \mathrm{a}$ & $100( \pm 0) \mathrm{a}$ \\
\hline St. carp. All & $3.3( \pm 5.8) d$ & $35.9( \pm 7.6) b$ & $88.4( \pm 11.5)$ a & $100( \pm 0.0) \mathrm{a}$ \\
\hline Het. bact. H06 & $23.3( \pm 15.3) \mathrm{dc}$ & $39.2( \pm 5.6) b$ & $92.6( \pm 6.4) \mathrm{a}$ & $100( \pm 0.0) \mathrm{a}$ \\
\hline CV & 21.76 & 3.13 & 8.82 & - \\
\hline \multicolumn{5}{|l|}{ Bioassay 3} \\
\hline St. sp. RW14-M-C2a-3 & $96.7( \pm 5.8)$ a & $100( \pm 0.0)$ a & $100( \pm 0.0)$ a & $100( \pm 0.0) \mathrm{a}$ \\
\hline St. sp. RW14-M-C2b-1 & $96.7( \pm 5.8)$ a & $100( \pm 0.0) \mathrm{a}$ & $100( \pm 0.0)$ a & $100( \pm 0.0) \mathrm{a}$ \\
\hline St. carp. RW14-G-R3a-2 & $70.0( \pm 0.0) b$ & $96.3( \pm 10.9) a b$ & $100( \pm 0) \mathrm{a}$ & $100( \pm 0.0) \mathrm{a}$ \\
\hline Het. bact.RW14-N-C4a & $46.7( \pm 5.8) \mathrm{C}$ & $85.6( \pm 6.8) b$ & $96.3( \pm 6.4) a b$ & $100( \pm 0.0) \mathrm{a}$ \\
\hline St. carp. All & $0.0( \pm 0.0) \mathrm{e}$ & $17.4( \pm 10.9) \mathrm{C}$ & $84.7( \pm 6.1) b$ & $100( \pm 0) .0 \mathrm{a}$ \\
\hline Het. bact. H06 & $26.7( \pm 5.8) d$ & $92.6( \pm 6.4) a b$ & $95.8( \pm 7.2) a b$ & $100( \pm 0.0) \mathrm{a}$ \\
\hline CV & 8.40 & 7.82 & 4.84 & - \\
\hline
\end{tabular}

St =Steinernema; Het = heterorhaditis; St carp = steinernema carpocapsae; Het bact = Heterorhabditis bacteriophora; $C V$ = coefficient of variatiation; mean followed by different letters in the same column within the same bioassay are significantly different according to Tukey's test $(P<0.05)$

and selection as emphasized by Sharma et al. (2011) and Biondi et al. (2018) in a view to boost their efficacy of EPNs. The highest efficacy of local EPN isolates than the exotics could be explained by the fact that these EPNs were isolated in Rwanda (Yan et al. 2016), and they might be more adapted to the local conditions than the exotics, which were isolated in a completely different environment. These results agree with the earlier findings where locally isolated biological control agents, including EPNs, performed better than exotics (Lima et al. 2017).

The highest pathogenicity of EPN isolates belonging to Steinernema genus than Heterorhabditis had also been reported by Batalla-carrella et al. (2010) who obtained 76.3\% mortality of $T$. absoluta larvae inside the leaf galleries using $H$. bacteriophora, while it was 88.6 and $92.0 \%$, using $S$. carpocapsae and $S$. feltiae, respectively, at a dosage of $60 \mathrm{IJs} / \mathrm{cm}^{2}$. Furthermore, Steinernema genus was observed to be the most virulent among different EPN species by different other researchers (Van Damme et al. 2016; Mutegi et al. 2017, and Kamali et al. 2018) which is inconsistent with the obtained findings.

Higher efficacy of EPNs belonging to Steinernema genus could be due to the bacteria associated with their genus and ambusher strategy for host scavenging with standing and jumping behaviors, which helps them to attach on the host (Lacey and Georgis, 2012 and Campos-Herrera, 2015). Furthermore, it was reported that some species of Steinernema genus possess both cruiser and ambusher strategies; which make them more efficient in finding their host. The stand and jump behaviors as well as this intermediate foraging strategy have not been reported in Heterorhabditis genus (Lewis et al. 2006). However, because of their dorsal tooth EPNs belonging to Heterorhabditis genus would be expected to penetrate directly the insect body through the thin wall area between the segments (Griffin et al. 2005), and they would be more 
pathogenic than Steinernema genus. However, this thought was not evidenced by the results of the present study.

It is established that after EPNs have entered the host, the bacteria cells released by the IJs multiply quickly and kill the host in 24-72 h after infection (Gözel and Kasap, 2015 and Van Damme et al. 2016). This was verified in the present study where all local EPN isolates caused between 53.3 and $96.7 \%$ mortality just within the first $24 \mathrm{~h}$ after inoculation, while in $72 \mathrm{~h}$, they all had caused between 96.3 and $100 \%$ mortality. This is not the case of other entomopathogens like entomopathogenic fungi, which require 3-5 days or even more time to kill their host (Reda and Hatem, 2012). The quick kill behavior of EPNs is beneficial for foliar applications where it can be guaranteed that before EPNs are killed by adverse environmental conditions such as desiccation and ultraviolet light, they would have searched, found and invaded their hosts in leaf galleries. Kim et al. (2006) reported that EPNs were able to survive $12 \mathrm{~h}$ after foliar spray on Chinese cabbage. This gives hope that application of EPNs on the aboveground part of the plant would yield good results because EPNs will have at least $12 \mathrm{hrs}$ to find and invade the host no matter whether it is on the leaf surface or inside the leaf gallery where more convenient environment is guaranteed for survival.

During this study, one fixed dosage of $500 \mathrm{IJs} / \mathrm{ml}$ was used because the main purpose was to screen the local EPNs isolates and find out the most effective ones against T. absoluta for further investigations. Other researchers found that the higher the dosage, the higher the efficacy. For instance, Youssef (2015) observed that with 3 dosages of 250, 500, and $1000 \mathrm{IJs} / \mathrm{ml}$ for $S$. carpocapsae, mortality rates of $T$. absoluta larvae reached to 80,100 , and $100 \%$, respectively. A similar trend was obtained by Batalla-Carrera et al. (2010), Mutegi et al. (2017), Yuksel et al. (2018), and Kajuga et al. (2018) on various pests. This could be due to the fact that high number of EPNs would result in high number of symbiotic bacteria released in the host's body and thus enhanced killing speed owing to increase digestion of host tissues by toxins and hydrolytic enzymes secreted by these bacteria (Van Damme et al. 2016).

The observed efficacy and rapid action of EPNs make them able to compete with conventional insecticides that are preferred owing to their quick action among others (Macharia et al. 2009 and Biondi et al. 2018). The safety, high virulence, ability to actively search for their hosts, mass production possibility, and compatibility with many pesticides are the other traits, which make EPNs a good option in IPM and potential substitutes to synthetic insecticides (Lima et al. 2017). Thus, further investigations should be carried out to determine their effectiveness under field conditions.

\section{Conclusion}

The results of this study revealed that local EPN isolates were able to find and kill $T$. absoluta larvae inside the leaf galleries under laboratory conditions and their efficacy increased with exposure time. The efficacy of local EPN isolates was significantly superior to that of the exotic species. This is the first study carried out in Rwanda on the potential of locally isolated EPNs against T. absoluta. The results of this study form the basis for further research. High EPN efficacy obtained under laboratory conditions cannot easily be extrapolated to field efficacy. Therefore, field experiments on tomato crop are justified to fully determine the potential of local EPN isolates against $T$. absoluta in Rwandan conditions.

\section{Abbreviations \\ EPN: Entomopathogenic nematodes; FAO: Food Agriculture Organization; GLM: General linear model; HSD: Honestly significant difference; \\ IPM: Integrated pest management; P: Probability; RAB: Rwanda Agriculture and Animal Resources Development Board; SAS: Statistical Analysis System package}

\section{Acknowledgements}

Authors would like to express gratitude to Rwanda Agriculture and Animal Resources Development Board (RAB) and Egerton University for their great contribution toward the achievement of this work. Special thanks go out to Mr Kagiraneza Boniface, Ms Bancy W. Waweru, Ms Kajuga Joelle and Dr

Rukundo Placide for their inspirations and technical support throughout this study. Mr Bazagwira Didace, Ms Ingabire Geraldine and Ms Ishimwe

Mukundwa Primitive are also acknowledged for their assistance in laboratory work.

\section{Authors' contributions}

All authors jointly designed the experiment. AN conducted the laboratory bioassays, performed data analysis and drafted the manuscript with inputs from all authors. SN, PM and SG collaborated closely with AN in the whole process especially during data analysis. All authors read and approved the final manuscript.

\section{Funding}

This material is based upon work supported by United States Agency for International Development, as part of the Feed the Future initiative, under the CGIAR Fund, award number BFS-G-11-00002, and the predecessor fund the Food Security and Crisis Mitigation II grant, award number EEM-G-00-0400013.

\section{Availability of data and materials}

The datasets used and/or analyzed during the current study are available from the corresponding author on reasonable request.

Ethics approval and consent to participate

Not applicable

Consent for publication

Not applicable

\section{Competing interests}

The authors declare that they have no competing interests.

Received: 10 May 2019 Accepted: 20 August 2019

Published online: 27 August 2019

\section{References}

Batalla-Carrera L, Morton A, García-del-Pino F (2010) Efficacy of entomopathogenic nematodes against the tomato leafminer, Tuta absoluta, in laboratory and greenhouse conditions. BioControl 55(4):523-530 
Biondi A, Guedes RNC, Wan FH, Desneux N (2018) Ecology, worldwide spread and management of the invasive South American tomato pinworm, Tuta absoluta: past, present, and future. Annu Rev Entomol 63:239-258

Blake G, Sandler HA, Coli W, Pober DM, Coggins C (2007) An assessment of grower perceptions and factors influencing adoption of IPM in commercial cranberry production. Renew Agric Food Syst 22(2):134-144

Brévault T, Sylla S, Diatte M, Bernadas G, Diarra K (2014) Tuta absoluta Meyrick (Lepidoptera: Gelechiidae): a new threat to tomato production in subSaharan Africa. Afr Entomol 22(2):441-444

Campos-Herrera R (2015) Nematode pathogenesis of insects and other pests. Ecology and Applied Technologies for Sustainable Plant and Crop Protection. Springer Exotics Publishing Switzerland, pp 532

Clay D, Turatsinze J (2014) Baseline report on the Rwanda Horticulture Organisations Survey. AGRER Consortium, pp 92

Desneux N, Wajnberg E, Wyckhuys KAG, Burgio G, Arpaia S, Narváez-Vasquez CA et al (2010) Biological invasion of European tomato crops by Tuta absoluta: Ecology, geographic expansion and prospects for biological control. J Pest Sci 83(3):197-215

FAO (2015) Quarterly Early Warning Bulletin for Food and Agriculture, JanuaryMarch 2015(14):18

Ferracini C, Ingegno BL, Navone P, Ferrari E, Mosti M, Tavella L, Alma A (2012) Adaptation of indigenous larval parasitoids to Tuta absoluta (Lepidoptera: Gelechiidae) in Italy. J Econ Entomol 105(4):1311-1319

Garcia-del-Pino F, Alabern X, Morton A (2013) Efficacy of soil treatments of entomopathogenic nematodes against the larvae, pupae and adults of Tuto absoluta and their interaction with insecticides used against this insect. BioControl 58(6):723-731

Gebremariam G (2015) Tuta Absoluta : A Global Looming Challenge in Tomato Production, Review Paper. J Biol Agric Healthc 5(14):57-63

Gözel Ç, Kasap I (2015) Efficacy of entomopathogenic nematodes against the Tomato leafminer, Tuta absoluta (Meyrick) (Lepidoptera: Gelechiidae) in tomato field. Turk Entomol Derg 39(3):229-237

Griffin C, Boemare N, Lewis EE (2005) Biology and behaviour. In: Greval, P., Ehlers, R.-U., Shapiro-llan, D (Eds.), Nematodes as biocontrol agents. CABI Publishing, Wallinford, Oxon, UK, pp 47-64

Haddi K, Berger M, Bielza P, Rapisarda C, Williamson MS, Moores G, Bass C (2017) Mutation in the ace-1 gene of the tomato leaf miner (Tuta absoluta) associated with organophosphates resistance. J Appl Entomol 141(8):612-619

Holmes KA, Chen J, Bollhalder F, UnSil R, Waweru B, Li H, Toepfer S (2015) Designing factories for nematode-based biological control products for an alternative, environmentally friendly management of soil insect pests. Afr J Agric Res 10:4432-4448

Kajuga J, Hategekimana A, Yan X, Waweru BW, Li H, Li K et al (2018) Management of white grubs (Coleoptera: Scarabeidae) with entomopathogenic nematodes in Rwanda. Egypt J Biol Pest Co 28(1):2

Kamali S, Karimi J, Koppenhöfer AM (2018) New Insight into the Management of the Tomato Leaf Miner, Tuta absoluta (Lepidoptera: Gelechiidae) with Entomopathogenic Nematodes. J Econ Entomol 111(1):112-119

Kaya HK, Stock PS (1997) Techniques in insect nematology. In: Lacey LA (ed.), Manual of Techniques in Insect Pathology. Biological Techniques Series,Academic Press, San Diego, pp. 281-324

Kim HH, Jeon HJ, Cho CY, Lee DW, Choo HY (2006) Persistence of entomopathogenic nematode, Steinernema carpocapsae GSN1 strain on vegetable leaf in greenhouses. Korean J Sci Technol 24:198-204

Lacey LA, Georgis R (2012) Entomopathogenic nematodes for control of insect pests above and below ground with comments on commercial production. J Nematol 44(2):218-225

Laznik Ž, Trdan S (2015) Failure of entomopathogens to control white grubs (Coleoptera: Scarabaeidae). Acta Agric Scand 65(2):95-108

Lewis EE, Campell J, Griffin C, Kaya H, Peters A (2006) Behavioral ecology of entomopathogenic nematodes. Biol control 38:66-79

Lima MD, Pascual PRL, Alburo HMA (2017) Heterorhabditis taysearae and heterorhabditis bacteriophora: Promising Indigenous. J Agri Tech Manag 20(2):8-13

Macharia I, Mithofer D, Waibel H (2009) Potential Environmental Impacts of Pesticides use in the Vegetable Sub-Sector in Kenya. Afr J Hort Sci 2:138-151

Mahmoud MF (2016) Biology and use of entomopathogenic nematodes in insect pests biocontrol, a generic view. Cerc Agron Mold 49(4):85-105

Mutegi DM, Kilalo D, Kimenju JW, Waturu C (2017) Pathogenicity of selected native entomopathogenic nematodes against tomato leaf miner (Tuta absoluta) in Kenya. World J Agric Res 5(4):233-239
Navon A, Ascher KRS (Eds.) (2000) Bioassay of entomopathogenic microbes and nematodes. Cabi

Ndabamenye T, Van Asten PJ, Blomme G, Vanlauwe B, Uzayisenga B, Annandale $J G$, Barnard RO (2013) Nutrient imbalance and yield limiting factors of low input East African highland banana (Musa spp. AAA-EA) cropping systems. Field Crops Res 147:68-78

Püntener W (1981) Manual for field trials in plant protection. Second edition. Agricultural Division, Ciba-Geigy Limited

Rangaswamy R (2013) Textbook of agricultural statistics. New age International, New Delhi, p 531

Reda AM, Hatem AE (2012) Biological and eradication parameters of the tomato leaf miner, Tuta absoluta (Meyrick) (Lepidoptera: Gelechiidae) affected by two biopesticides. Bol San Veg Plagas 38:321-333

SAS Institute Inc (2010) SAS ${ }^{\oplus} 9.2$ companion for windows, second edition. SAS Institute Inc, Cary, NC

Sharma MP, Sharma AN, Hussaini SS (2011) Entomopathogenic nematodes, a potential microbial biopesticide: mass production and commercialisation status - a mini review. Arch Phytopathology Plant Protect 44(9):855-870

Stock P (2015) In: Campos-Herrera R (ed) Nematode Pathogenisis of Insects and Other PestsDiversity, biology and evolutionary relationships. Springer, Cham, pp 3-28

Van Damme VM, Beck BK, Berckmoes E, Moerkens R, Wittemans L, De Vis R et al (2016) Efficacy of entomopathogenic nematodes against larvae of Tuta absoluta in the laboratory. Pest Manag Sci 72(9):1702-1709

White GF (1927) A method for obtaining infective nematode larvae from cultures. Science (Washington) 66(1709)

Wraight SP, Lopes RB, Faria M (2017) Microbial control of mite and insect pests of greenhouse crops, pp.237-252. In L. Lacey (ed.), microbial control of insect and mite pests. Academic Press, San Diego, CA

Yan X, Waweru B, Qiu X, Hategekimana A, Kajuga J, Li H et al (2016) New entomopathogenic nematodes from semi-natural and small-holder farming habitats of Rwanda. Biocontrol Sci Techn 26(6):820-834

Youssef AN (2015) Efficacy of the entomopathogenic nematodes and fungi for controlling the tomato leaf miner, Tuta absoluta (Meyrick) (Lepidoptera : Gelechiidae). Arab Univ J Agri Sci 23(2):591-598

Yuksel E, Taskesen YE, Erarslan D, Canhilal R (2018) Effectiveness of different entomopathogenic nematode species against the variegated cutworm, Peridroma saucia (Hubner) (Lepidoptera: Noctuidae). Egypt J Biol Pest Co 28:8

\section{Publisher's Note}

Springer Nature remains neutral with regard to jurisdictional claims in published maps and institutional affiliations.

\section{Submit your manuscript to a SpringerOpen ${ }^{\circ}$ journal and benefit from:}

- Convenient online submission

- Rigorous peer review

- Open access: articles freely available online

- High visibility within the field

- Retaining the copyright to your article

Submit your next manuscript at $\boldsymbol{\nabla}$ springeropen.com 